\title{
HYPOPHYLAX, HYPOCNEMOIDES AND MYRMODERUS (AVES, FORMICARIIDAE) AS ARMY ANT FOLLOWERS
}

EDWIN O. WILLIS

\begin{abstract}
Hylophylax naevia of moderately dense forest undergrowth and $\mathrm{H}$. punctulata of open swamp undergrowth tend to sally for arthropods in low foliage rather than sally to the ground among large ant-following antbirds. They and related Hypocnemoides melanopogon of swamp understory edges are also limited by their microhabitat niches in following ants. Myrmoderus ferrugineus and M. loricatus, ground-walking small antbirds seemingly derived from Hylophylax, follow ants infrequently, probably because ants, large ant-following birds, and predators would attack them if they did so.

Some antbirds of the genus Hylophylax regularly capture flushed arthropods over swarms of army ants (Willis, 1972; Willis \& Oniki, 1978; Willis, in press). Here, in the nineteenth report of a series on occasional ant followers, I note observations of related species of the genera Hylophylax, Hypocnemoides, and Myrmoderus
\end{abstract}

\section{RESULTS}

1. Hylophylax naevia (Spot-backed Antbird) was recorded at 37 scattered ant raidis (1 Umbria, Putumayo, and 6 Mitú, Vaupés, Colombia; 1 Zatzayacu, 5 Limoncocha, 3 Yaapi, and 2 Putuimi, Ecuador; 2 San Alejandro and 1 Andoas, Loreto, Peru; 6 Coatá, 9 Maloquinha, and 1 Miritituba, Brazil). All were raids of Eciton burchelli except for a Labidus praedator raid with 2 birds at Putuimi and 3 such raids with a total of 4 birds at Mitú. $E$. burchelli raids with 2 birds each were these: 1 Zatzayacu, 1 Limoncocha, 2 Yaapi, 2 San Alejandro, 1 Andoas, 4 Coatá (plus 1 with 3 birds), and 2 Maloquinha (plus 1 with 3 birds). Occasionally naevia were irregularly present over 6 hours, but most wandered past and left raids within a few minutes.

This species, which weighs only $13.6 \mathrm{~g}$ (male at Maloquinha; cloacal temperature $42.7^{\circ} \mathrm{C}$ ) in contrast to $17.5 \mathrm{~g}$ for $H$. naevioides across the Andes, rarely follows ants. It wanders low (27-9-3-1 records 0-4 $\mathrm{m}$ up, by $1-\mathrm{m}$ intervals, in various regions) on slender (4-1 records at $0-2 \mathrm{~cm}$ diameter) vertical (6) or inclined (2) sprouts and bushes in the moderately open forest understory, retreating to nearby denser cover when disturbed. Unlike naevioides, it infrequently sallies to the ground for

Department of Biology, University of Miami, Coral Gables, Florida 33124 U.S.A., and Departamento de Zoologia, Universidade Estadual Paulista "Júlio de Mesquita Filho" - UNESP, Caixa Postal 178, Rio Claro, S. Paulo. 
prey: in various regions, there were 4 such records for naevia in contrast to 10 records to above-ground sites (4 foliage, 3 lianas, 2 air, 1 $\log )$. It sometimes flies a short distance and pecks prey off low foliage ( 8 records), a liana (1), trunk (1), or other (1) vegetation. Short periods of standing and looking about lead to flights to nearby prey above the ground, a prey-searching method that requires an understory that is neither dense enough for gleaning relatives (such as Myrmotherula hauxwelli) nor open enough either for the long-distance sallies of other relatives (notably Hylophylax poecilinota) or for significant reduction in prey density. At Maloquinha, a poecilinota supplanted a naevia and a Rhegmatorhina berlepschi displaced one, while a $R$. hoffmannsi plus a poecilinota displaced a naevia at Coatá. Active competition from numerous species of Amazonian ant-following antbirds may keep naevia from becoming such a ground-sallying and regular ant follower as naevioides, thereby forcing naevia to maintain its small size and short-distance flycatching abilities. Little prey is flushed by ants up on the shrubs of the forest understory, perhaps accounting for the fact that naevia follows ants infrequently.

Other than in its foraging behavior, naevia closely resembles naevioides. The calls are similar (in naevia, the «song» is a descending beee tiksee tiksee tiksee, sometimes alternating with peup «chirps» as

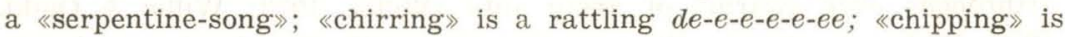
a set of 1-6 peep notes at the fast rate of $4 / \mathrm{sec}$; «bugling» is a chwit call; «snarling» is a nasal wrieeeeh; young «peepsing» chut-chut-chut pee pee pee pee and «squeak» chwaihh notes), except that all the calls of naevia seem faint and sibilant or high-pitched compared to calls of its larger relative naevioides. In alarm, it flicks the tail up to the line of the body just as does naevioides. In disputes, the white back and white-tipped tail are spread as in naevioides, although the lighter naevia pivots back and forth more often. The white breast flashes with each tiksee phrase in a song, as in naevioides. Pairs chirp and «faint-sing》 to each other as they wander separately near or away from ants.

$H$. naevioides is common in many forest types and understory types west of the Andes, for it forages largely on the ground. H. naevia, requiring moderately dense low foliage, is absent both in dry and relatively open forest an in dense ground cover or open flooded zones along swamps. I have seen it in mossy forests at $900-1100 \mathrm{~m}$ on the eastern slope of the Andes (Mera and Zatzayacu, Ecuador), and at scattered localities east of the Andes, but it is decidedly local and uncommon in most areas compared to naevioides.

2. Hylophylax punctulata (Dot-backed Antbird) attended 7 Eciton burchelli raids in the open seasonally-flooded understory of várzea swamps at Maloquinha, where nuevia stayed in the nearby moderately cluttered terra firme forest understory. All records for punctulata were of a family of 3 birds except for at least 4 birds in a 2-pair dispute along a creek one day. They sometimes wandered near the ants for 3-4 hours, but deserted at once whenever the ants entered terra firme understory . 
$H$. punctulata takes the flycatching tendencies of naevia a step further, for punctulata normally stands like a short-legged Platyrinchus flycatcher in or just below leaves at the high-water mark, sallying or fleeing by a descent through the open understory of the várzea. Horizontal (2) or slightly inclined (2 to $50^{\circ}$ ) perches of varying diameter (1-8 cm) at about $2 \mathrm{~m}$ up (4-4-1-2 records from 0-4 $\mathrm{m}$ up) were used, like a flycatcher rather than like its vertical-clinging relatives. One prey was pecked off a trunk, and 13 were taken by short-distance sallies ( 6 foliage, 4 air, 1 each liana, stem, and ground). It darts long distances from one perch to another, especially when alarmed. Its alarm calls include a sharp bee-bee-beet and a loud steeyou descending call, the latter given with an upward flick of the tail. The «song» seems to be a set of 1-3 loud weebeeyou phrases, reminding one of the song of the Traill's Flycatcher (Empidonax traillii). In disputes, the closed tail is jerked to $45^{\circ}$ above the line of the horizontal body, and may be held upripht like that of a wren to show the fluffed white undertail coverts. The white back patch is open, framed by the dots at the margins of the back. The head angles upward to show the throat at the opponent. Often the bird crouches during this head-and-tail-up display, but one female briefly stood high on her bluish-white legs as she displayed after fleeing. One male gave a faint wrieeeh «snarl» and flew at another, supplanting him in a flurry of bee-bee-beet calls.

The main pair at Maloquinha may have been unusually wary because they were feeding a nearly-grown young female out of the nest, 23-27 Feb 1966. The young female lisped wheesp-yerp every 10-20 sec or gave riehh faint squeaks, flicking her tail for each note; once she was silent and once she «squeaked» rapidly as fed. The male gave faint peup «chirps» to her and to the mate.

Flycatching through the open understory of seasonally flooded swamps restricts the ant following of this species to occasional raids that enter the swamps, while ants flush rather little prey on foliage. However, the swamp colony of ants at Maloquinha was attended rather persistently, so that the species may capture much prey over ants.

3. Hypocnemoides maculicauda (Band-tailed Antbird) attended 7 várzea raids of Eciton burchelli at Maloquinha and 17 at Belém. Pairs were at all raids but 3 at Maloquinha ( 2 with 1 bird, 1 with 4) and 3 (with 1 bird each) at Belém. In all regions they stay near or over water in swamps. Like their relatives, they seldom move into sunlight; one in a sunny treefall at Belém twitched one wing out spastically as if starting «sunning» behaviour. At Belém, they hopped low (35-17-4-2 records 0-4 $\mathrm{m}$ up, by $1-\mathrm{m}$ intervals) on mostly horizontal (19-7-2-4-3 records from $0^{\circ}$ to 100 ' with the horizontal, by $20^{\circ}$ intervals) twigs to palm fronds (17-6-6-0-1 records from 0-5 cm diameter, then 2 records to $15 \mathrm{~cm}$ diameter). Long bills, which barely separate this genus from Hylophylax, suggest that maculicauda peck prey rather long distances from semiopen perches; and at Maloquinha they did glean prey twice from debris and once from a trunk. However, I recorded even more short sallies both there ( 2 to ground, 1 to a trunk for a moth, 1 to foliage) and at Belém ( 3 to ground, 3 to foliage, 1 to air, 1 to a liana). 
The Band-tailed Antbird hops and peers actively in low lianas, palms, and other somewhat cluttered vegetation. Jerking or flicking the tail from $10^{\circ}$ up to $50^{\circ}$ above the line of the body every second or two as if to display its pale tip, the bird may give sharp peep-peep or similar «chipping» in alarm (once to a Gray Hawk, Buteo nitidus). At a human, it gives a de-e-e-e-e «chirr» or «rattle» or a faint wrieeh «snarl». The tail waggles rapidly as pairs «sing» rapid series of peet notes ending in several snarling pry notes. One male at Maloquinha posed with bill up and throat, remiges, and rectrices spread at an opponent male, which hopped around jerking its spread tail rapidly from $30^{\circ}$ up to $50^{\circ}$ above the horizontal. Most records at Belém were of a color-banded pair (male $14.7 \mathrm{~g}$, cloacal temperature $43.0^{\circ} \mathrm{C}$; female $14.0 \mathrm{~g}$ ) that kept for themselves a swamp zone about $300 \mathrm{~m}$ long. Restriction to moderately cluttered water edges in swamps prevents them from following ants regularly, as they never move into the more vertically oriented seedling; of terra firme forest even if the ants move there from seasonally flooded areas. The maculicauda are somewhat subject to attacks by regular ant followers as they hop near ants: at Belém, Pyriglena leuconota twice supplanted and once displaced a maculicauda, while Dendrocincla merula twice supplanted one. At Belém, they prefer seasonally flooded semiopen pools to forest channels or to cul-de-sacs flooded twice daily by tides. At Maloquinha, they used stream or backwater edges and low vines or roots, as much as $2 \mathrm{~m}$ below the rarely-flooded leafy understory «roof» preferred by $H$. punctulata.

4. Myrmoderus ferrugineus (Ferruginous-backed Antbird) followed 1 Eciton burchelli raid at Nappi Creek, Guyana (Oniki \& Willis, 1972) and 58 raids at Reserva Ducke, Brazil. Pairs were at the Guyana raid and at 19 raids at Reserva Ducke. Most visits were brief, but a few birds were irregularly present 200-280 min.

This long-tailed walking antbird seems at first very different from Hylophylax, but is linked to that genus by short-tailed Dichrozona cincta (Banded Antbird), which is little more than a walking Hylophylax. (Behaviorally, cincta strikingly resembles unrelated nightingale wrens, Microcerculus species). I presume that Dichrozona, Myrmoderus, Myrmorchilus, and Myrmornis represent a ground-walking radiation (extended to leaf-tossing in the case of Myrmornis) from ancestors related to Hylophylax and Hypocnemoides, which themselves have radiated more toward flycatching or ground-sallying niches.

Neither Dichrozona, Myrmorchilus nor Myrmornis are yet recorded with ants, although I have seen all but Myrmorchilus near ants; but rarity of ant following is characteristic of nearly all small ground-foraging insectivores, including $M$. ferrugineus. Two problems are that small walking birds are easily sttacked by ants, hence have to circle them warily, and that large birds tend to dominate prey-rich areas near ants, forcing small birds even further out. A third problem is that groups of birds near ants attract predators, and ground birds in general avoid bird flocks. $M$. ferrugineus normally walks on the ground and over roots or logs 5 or more $m$ from ants, and deserts them readily. 
At sunny spots in the forest interior, ferrugineus is often replaced by lizards of Ameiva or Kentropyx; ferrugineus and similar antbirds are the «lizards» of shade. Few ferrugineus were seen to capture prey near ants: 8 pecked tiny items from the leaf litter, and one ran and jumped to snap small prey from the air. Only once was one supplanted near ants, by a Black-headed Antbird (Percnostola rufifrons).

Alarmed ferrugineus give dit-it or even longer series of «chipping» notes, also (at least at humans) a dre-e-e-e-e-e-e «rattle» or «chirr». They «flick their tails upward like Hylophylax rather than «pound» the tails downward like antbirds of the genus Myrmeciza. Pairs can be detected in dense ground vegetation by warbling «songs», series of 2-10 tike notes like a Hylophylax naevia from the male answered by infrequent tee-tee-tee-tee-tee-tikee-tikee-tee-tee songs from the female.

5. Myrmoderus loricatus (White-bibbed Antbird) followed 2 Eciton burchelli raids at Boa Nova, Bahia, 1 at Fazenda Três Pancadas (Ituberá, Bahia), and 1 at Sete Barras Reserve, São Paulo. Pairs were at both Boa Nova raids. Most visits were brief, for this species normally forages on the ground away from ants; but one Ituberá bird stayed near ants for $6 \mathrm{~h}$. While loricatus resembles ferrugineus in plumage, foraging behavior, and in flicking the tail upward in alarm, it hops rather than walks on the forest floor. At Ituberá, 3 prey were pecked from the ground, 2 pecked off low trunks by jumping, and 1 each captured by short upward sallies to air, a leaf, and debris. Alarm notes include pseek «chips» and de-e-e-e-e-ee «rattles», while the «song» (at Boa Nova) is a wee tivee tivee tivee tivee tivee or similar series.

\section{DISCUSSION}

Regular ant following is recorded for two members of the genus Hylophylax, one a bird of Central American forests (which have relatively low ant-following diversity; Willis, 1972) and the other an Amazonian species with the unusual ability to cling inconspicuously to large trunks in the open forest understory away from larger competitors (Willis \& Oniki, 1978; Willis, in press). Two other Hylophylax and one related Hypocnemoides are even smaller birds that have little chance to persist among large and aggressive birds over ants. These three species have radiated instead into other niches, flycatching low in moderately dense terra firme understory (naevia) and in open floodplain understory (punctulata) or moving low along moderately dense swamp edges (maculicauda) With restriction to specific microhabitats, they become even less able to follow nomadic ants, but in their microhabitats they sometimes follow ants persistently.

Another evolutionary line from the genus Hylophylax, if morphology (shape, spotted colors) and certain behavioral patterns (voice; flicking the tail upward in alarm) are good indicators, leads through Dichrozona cincta, a walking ground antbird very like Hylophylax, to longer-tailed ground birds of the genera Myrmoderus, Myrmornis, and perhaps Myrmorchilus (a tail-flicking antbird of bushes in dry areas). Ground-living 
birds of small size cannot walk among aggressive ants, and tend to be excluded even from zones near ants by large ground birds (from rails, trumpeters, and ground-cuckoos down to large antthrushes of the genus Formicarius). Apparently exclusion to zones more than about $5 \mathrm{~m}$ from ants reduces prey capture so much that Dichrozona and Myrmornis are not yet recorded with ants, while Myrmoderus are recorded only infrequently wandering around ant raids. Another problem for ground birds is that most avoid bird flocks, perhaps because subject to predation if in flocks. Probably ground antbirds of this evolutionary line find prey as well or better away from as near ants.

\section{ACKNOWLEDGMENTS}

I appreciate grants from the National Science Foundation (especially GB-32921), the Chapman Fund of the American Museum of Natural History, and the National Geographic Society. The help of the Instituto Nacional de Pesquisas da Amazônia at Manaus, of the Instituto Agronômico and Museu Paraense Emílio Goeldi at Belém, and of the Instituto Florestal in São Paulo is gratefully acknowledged. Douglas Wechsler helped with data collection at Manaus. Yoshika Oniki helped in many ways.

\section{REFERENCES}

Willis, E. O., 1972. The behavior of Spotted Antbirds. A. O. U. Monog. 10:1-162.

Willis, E. O., in press. The behaviour of Scale-backed Antbirds (Hlophylax poecilinota). Wilson Bull.

Willis, E. O. \& Y. Oniki, 1978. Birds and army ants. Ann. Rev. Ecol. System. $9: 243-263$. 